\title{
PAPÁ TÚ DICES NO HAY MUCHO QUE VER
}

pero siempre me acompañas

y yo digo que nunca pensé en el terror que quizás

también sentías al mirarte

ni en la tristeza que siempre te mantuvo suspendido

que nunca pensé en los objetos colmados de miedo contemplándose en la luz que desprendías

ni el calor que por momentos los iluminó

que nunca pensé en las constelaciones que se

derramaban por tus ojos más allá de la noche

ni en la forma en la que solías detenerte a mitad de

todo y sonreír

que nunca pensé en la estrechez del cuarto y lo

inmensos que éramos al encendernos y apagarnos

ni en lo mucho que contábamos cuando yo aprendía a seguir tus pasos

y tu mano me sostenía de caer

en ese tiempo no existía pequeña tan pequeña como la que ahora soy

porque nadie nunca había llegado hasta ahí

y yo era para ti toda la vida todo el amor y la ternura

a cada paso

y cada yo una extensión de ti

que por momentos creías reconocer 